Arq. Bras. Med. Vet. Zootec., v.69, n.4, p.915-920, 2017

\title{
Retrospective study of ocular complication following phacoemulsification with intraocular acrylic lens implantation in dogs
}

\author{
[Estudo retrospectivo das complicações oculares em cães submetidos à facoemulsificação \\ com implantação de lente acrílica] \\ T.G. Guimarães ${ }^{1}$, C.S. Honsho ${ }^{1}$, F.V. Mamede $^{2}$, F.G.G. Dias ${ }^{1}$, D.S. Anjos ${ }^{1}$, \\ L.F. Pereira ${ }^{1}$, I. Ricordi ${ }^{1}$, A.T. Jorge ${ }^{1 *}$ \\ ${ }^{1}$ Universidade de Franca -Franca, SP \\ ${ }^{2}$ Médico veterinário autônomo - Ribeirão Preto, SP
}

\begin{abstract}
The aim of this study was to analyze for 120 days, post-operative complications following bimanual phacoemulsification with implantation of hydrophilic or hydrophobic intraocular acrylic lens. The hospital records of 15 dogs were analyzed, and distributed in two groups, being Gfi and Gfo the hydrophilic intraocular lens and hydrophobic intraocular lens group, respectively. On the first day, both groups presented blepharospasm, conjunctival hyperemia and flare. On day 1, fibrin was slightly apparent in two and three eyes of Gfi and Gfo, and on day 7, present in one and two patients from Gfi and Gfo. Synechia was observed on day 1 in one eye from Gfi and Gfo. Two eyes from Gfi developed from 7 to 120 days, and in Gfo, one eye developed from 7 to 90 days, on day 120, two eyes formed them. The presence of posterior capsule opacity of the lens in all periods, there was no statistical significant between the groups. Only one eye, in Gfo, that had no opacity formation. The intraocular pressure of both groups remained within normal range. There was no statistical significance between hydrophilic and hydrophobic intraocular lens, the use of intraocular lens has led to satisfactory results in visual ability.
\end{abstract}

Keywords: cataract, phakectomy, hydrophilic lens, hydrophobic lens

\section{RESUMO}

Objetivou-se com o presente estudo avaliar por 120 dias as complicações após a facoemulsificação bimanual com implantação de lentes acrílicas hidrofílicas ou hidrofóbicas. Os prontuários de 15 cães foram avaliados, sendo distribuídos em dois grupos, Gfi e Gfo, grupos com lentes intraoculares hidrofílicas e com lentes hidrofóbicas, respectivamente. No primeiro dia, ambos os grupos apresentaram blefarospasmo, hiperemia conjuntiva e flare. No dia 1, fibrina foi discretamente observada em dois e três olhos do Gfi e Gfo; no dia 7, observou-se em um e três olhos nos pacientes do Gfi e Gfo. Foi observada sinéquia no dia 1 em um olho do Gfi e do Gfo; em dois olhos do Gfi ocorreu do dia 7 ao dia 120. No Gfo apenas um olho teve sinéquia do dia 7 ao dia 90, contudo aos 120 dias, dois olhos formaram-na. A opacidade de cápsula posterior da lente esteve presente em todos os períodos, não havendo diferença estatística entre os grupos. Somente um olho, do Gfo, não teve formação de opacidade. A pressão intraocular foi normal em ambos os grupos. Não houve diferença estatística entre as lentes hidrofílicas $e$ hidrofóbicas. $O$ uso de lentes intraoculares apresentaram resultados satisfatórios na acuidade visual.

Palavras-chaves: catarata, facectomia, lente hidrofílica, lente hidrofóbica

Recebido em 6 de junho de 2016

Aceito em 23 de agosto de 2016

*Autor para correspondência (corresponding author)

E-mail: adrianatjorge@hotmail.com 


\section{INTRODUCTION}

Cataract is the main cause of visual loss in dogs and phacoemulsification (PHACO) is the treatment of choice (Kuner et al., 2004; Pigatto et al., 2007; Kleiner, 2012). Post-operative follow up is essential for therapy success, aiding in the early identification of post-surgical complications that could compromise visual recovery (Teixeira, 2003; Gonçalves et al., 2005; Gordo, 2012).

The intraocular lenses (IOL) of dogs are anatomically different from those of humans (Azevedo and Ranzani, 2006), measuring from 13.5 to $17 \mathrm{~mm}$ (Gelatt and Wilkie, 2011) and possessing an optical power of 40 dioptre (Teixeira, 2003; Yi et al., 2006; Ofri, 2013). The materials commonly used in the manufacturing of canine intraocular lens are polymethyl methacrylate (PMMA), hydroxyethyl methacrylate (HEMA), silicone or acrylic (Davidson, 2001).

The acrylic lens, due to its flexibility, can be implanted through a 2.5 to $3.5 \mathrm{~mm}$ corneal incision, thus reducing the chances of astigmatism. It has great biocompatibility, hydrophobic or hydrophilic surface properties and minimal incidence of posterior capsule opacification (Kecova and Necas, 2004; Pereira et al., 2011). The hydrophilic and hydrophobic acrylics have a refraction index of 1.43 to 1.48 and 1.47 to 1.55 , respectively (Kecova and Necas, 2004).

The aim of this study was to analyse, for 120 days, the post-operative ophthalmic recovery of dogs subjected to PHACO with the implantation of hydrophilic or hydrophobic intraocular lens and to compare the two types of lenses used.

\section{MATERIAL AND METHODS}

This research followed the international guidelines from the Association for Research in Vision and Ophthalmology - ARVO (National Institutes of Health Publications number 85-23: Revised 1985) and was approved and overseen by the Ethics Committee on the Use of Animals from the Franca University (protocol number 029/14).
The surgical procedures were performed between January 2011 and February 2013. The hospital records of 15 dogs subjected to bimanual phacoemulsification with the implantation of hydrophilic or hydrophobic intraocular lenses were analysed on days 1, 7, 15, 30, 90 and 120 post-surgery.

The selection of patients, the surgical procedure and the pre and post-operative analysis were performed by the same Veterinary Ophthalmologist. The animals went through rigorous selection and standardization, and only animals that were docile, safe to handle and to medicate and that did not have any complications in the trans-operative period were chosen for this study. Furthermore, animals were subjected to ophthalmological, cardiac, haematological and urinary analysis prior to selection. Therefore, only 15 dogs (16 eyes) met the criteria of the present study and the strict selection minimized external interference on the results. Only one animal had surgery on both eyes.

One drop of ketorolac thromethamine (Cetrolac ${ }^{\circledR}$, União Química, Brazil) and one drop of gatifloxacin combined with prednisolone acetate $\left(\right.$ Zypred $^{\circledR}$, Allergan, Brazil) were administered topically every 6 hours, 3 days prior to the surgical procedure. Azithromycin $(20 \mathrm{mg} / \mathrm{kg})$ combined with $0.2 \mathrm{mg} / \mathrm{kg}$ meloxicam (Azicox$2^{\circledR}$, Ourofino, Brazil) was given orally 1 day prior to surgery.

Food and water were withheld for 8 and 6 hours prior to the surgical procedure, respectively. Animals were pre-medicated with $0.1 \mathrm{mg} / \mathrm{kg}$ acepromazine (Acepran ${ }^{\circledR}$, Vetnil, Brazil) and 2.0 $\mathrm{mg} / \mathrm{kg}$ pethidine chlorhydrate (Dolosal ${ }^{\circledR}$, Cristália, Brazil) intramuscularly. A drop of tropicamide eye drops (Mydriacyl 1\% ${ }^{\circledR}$, Alcon, Brazil) was applied and $0.5 \mathrm{mg} / \mathrm{kg}$ midazolam maleate (Dormonid $^{\circledR}$, Roche, Brazil) and 3 $\mathrm{mg} / \mathrm{kg}$ propofol (Propovan ${ }^{\circledR}$, Cristália, Brazil) were given intravenously 30 minutes later. The animals were kept under anaesthesia with isofluorane (Isoforine ${ }^{\circledR}$, Cristália, Brazil) diluted in $100 \%$ oxygen.

After clipping of the periocular area, the animals were kept in dorsal decubitus and antisepsis performed using 1:50 polyvinyl-pyrrolidone in saline and 1 drop of $1 \%$ tetracaine chlorhydrate and $0.1 \%$ phenylephrine chlorhydrate eye drops 
(Anestésico ${ }^{\circledR}$, Allergan, Brazil). Centralization of the ocular bulb was done through intravenous administration of $0.3 \mathrm{mg} / \mathrm{kg}$ rocuronium bromide (Rocuron $^{\circledR}$, Cristália, Brazil).

Bimanual PHACO was performed and a $2.75 \mathrm{~mm}$ scalpel (UniqueEdge ${ }^{\circledR}$, USA) used to make the main corneal incision at the 10 o'clock position, using a tunnelled approach. Subsequently, 0.1\% trypane blue (Ophthalmos ${ }^{\circledR}$, Brazil) was injected in the anterior chamber in order to visualize the anterior capsule of the lens. After 2\% hypromelose (Solucel ${ }^{\circledR}$, Oftalmopharma, Brazil) was administered to the anterior chamber; capsulorhexis, hydrodissection and lens rotation were performed. An auxiliary incision in the cornea was done using a $15^{\circ}$ scalpel blade (UniqueEdge $\AA$, USA) at the 2 o'clock position, aiding the manipulation of the lens during the procedure.

A surgical microscope (DF-Vasconcellos ${ }^{\circledR}$, Brazil) with 16x magnification was used in conjunction with a Universal II $^{\circledR}$ phacoemulsification system (Alcon, Brazil) with ultrasound power set at $60 \%$, pulse rate at $10 \mathrm{ppm}$, aspiration rate of $32 \mathrm{cc} / \mathrm{min}$ and vacuum of $400 \mathrm{mmHg}$. The mean time of ultrasound use was 1.2 minutes. A $500 \mathrm{~mL}$ lactated Ringer solution bag (JP Indústria Farmacêutica ${ }^{\circledR}$, Brazil) containing $0.4 \mathrm{~mL}$ epinephrine $\left(\right.$ Adren $^{\circledR}$, Hipolabor, Brazil) and $0.4 \mathrm{~mL}$ sodium heparin (Hepamax-S ${ }^{\circledR}$, Blausiegel, Brazil) was kept 110 $\mathrm{cm}$ above the animal's head.

Remains from the lens, posterior capsule polishing and viscoelastic material were removed by the irrigation and aspiration system. Hydrophilic (k9-650HSM ${ }^{\circledR}$, I-Med, Canada) or hydrophobic lenses (Siflex Vet ${ }^{\circledR}$, I-Med, Canada) were implanted in the capsular sac and $0.5 \mathrm{~mL}$ of carbacol (Ophthalmos ${ }^{\circledR}, \quad$ Brazil) was administered to the anterior chamber. The cornea was sutured with 10-0 nylon (Bioline ${ }^{\circledR}$, Brazil) using simple interrupted stiches and the knots buried.

At the end of the surgical procedure the dogs were given $0.05 \mathrm{mg} / \mathrm{kg}$ neostigmine methylsulphate (Prostigmine ${ }^{\circledR}$, Valeant, Brazil) combined with $0.04 \mathrm{mg} / \mathrm{kg}$ atropine sulphate $\left(\right.$ Pasmodex ${ }^{\circledR}$, Isofarma, Brazil) intravenously and $2 \mathrm{mg} / \mathrm{kg}$ tramadol (Tramal ${ }^{\circledR}$, Pfizer, Brazil) subcutaneously. Animals received subconjuctival injections of $0.25 \mathrm{~mL}$ gentamycin (Garamicina ${ }^{\circledR}$, Mantecorp, Brazil) (40 mg/mL) and $0.25 \mathrm{~mL}$ dexamethasone (Decadron ${ }^{\circledR}$, Aché, Brazil) $(2 \mathrm{mg} / \mathrm{mL})$.

One drop of thromethamine ketorolac $\left(\right.$ Cetrolac $^{\circledR}$, União Química, Brazil) and 1 drop of gatifloxacin combined with prednisolone acetate (Zypred $^{\circledR}$, Allergan, Brazil) were prescribed every 3 hours. Animals with intraocular pressure (IOP) above $20 \mathrm{mmHg}$ were given eye drops containing dorzalamide chlorhydrate and timolol maleate $\left(\mathrm{Cosopt}^{\circledR}\right.$, Merck Sharp \& Dohme, France). The duration of the ophthalmic therapy was determined according to the needs of each patient. Azithromycin $(10 \mathrm{mg} / \mathrm{kg})$ combined with meloxicam $(0.1 \mathrm{mg} / \mathrm{kg}) \quad\left(\right.$ Azicox $-2^{\circledR}$, Ourofino, Brazil) was given orally once a day, for 4 days.

The eyes subjected to PHACO were divided into two groups $(n=8)$ according to the type of intraocular lens implanted: hydrophilic (Gfi) and hydrophobic (Gfo).

For ophthalmological evaluation, a score of 0 was used in the absence of clinical signs and 1 in the presence of blepharospasm, accommodation, glare, direct and consensual pupillary reflexes, hyphema, hypopium, fibrin, vitreal bands and synechiae. The clinical signs of conjuctival hyperaemia, central corneal oedema, flare and posterior capsule opacification were classified according to their intensity: 0 (absent), 1 (discrete), 2 (moderate) and 3 (intense). Corneal oedema evaluation did not include the oedema caused by the main or auxiliary corneal incisions. The IOP was measured following the application of 1 drop of anaesthetic eye drops containing $0.5 \%$ proxymetacaine (Anestalcon ${ }^{\circledR}$, Alcon, Brazil) on the ocular surface. Three measurements were taken using an applanation tonometer (TonopenXL ${ }^{\circledR}$, Reichert, USA) with normal values being considered between 15 and $25 \mathrm{mmHg}$ (Gonçalves et al. 2005). Significance was considered at $5 \%$.

Mean, standard deviation (SD) and t-test were used to analyse IOP. Chi-square $\left(\mathrm{X}^{2}\right)$ was used to analyse gender, breed and stage of cataract maturation. Statistical analysis was performed using the software GraphPad Prism 5.0 (GraphPad Software, USA). Significance was considered at $5 \%$. 


\section{Guimarães et al.}

\section{RESULTS}

Two eyes from Gfi and one eye from Gfo showed blepharospasm on the first postoperative day. There was no significant difference $\left(X^{2}=0.06618\right.$ and $\left.P=0.9997\right)$ in the incidence of blepharospasm between the groups and periods analysed.

On the first post-operative day, conjunctival hyperaemia was observed in $3(37.5 \%)$ and 4 $(50 \%)$ dogs from Gfi and Gfo, respectively. No clinical signs of conjunctival hyperaemia could be seen on days $7,15,30$ and 60 post-operation. Only one animal from Gfi presented discreet conjunctival hyperaemia on day 120 postsurgery. No significant difference $\left(\mathrm{X}^{2}=0.1324\right.$ and $P=0.9993$ ) was observed in the incidence of conjunctival hyperaemia between the two groups.

There was no significant difference $\left(\mathrm{X}^{2}=0.40\right.$ and $\mathrm{P}=0.9992$ ) in the incidence of ocular flare between the groups. However, on day 1 postsurgery, most animals from both group showed signs of flare. As time elapsed, only one animal from Gfi showed any signs of flare on day 120 post-surgery.

On day 1 , fibrin was present in two animals from Gfi and in three from Gfo and by day 7 it was only present in one animal from Gfi and in two from Gfo. On day 15, fibrin was present in only one animal from Gfo. No fibrin was observed on the remaining days. No significant difference $\left(\mathrm{X}^{2}\right.$ $=0.1312$ and $\mathrm{P}=0.9998$ ) was observed in the incidence of fibrin between the groups.

Discreet hyphema was present in only one animal from Gfi on day 120 post-surgery; however, no significant difference $\left(\mathrm{X}^{2}=0.05615\right.$ and $\mathrm{P}=1.0$ ) was observed in the incidence of hyphema between the groups.

Synechiae was present in $25 \%$ of the animals of both groups for most of the period analysed but no significant difference $\left(\mathrm{X}^{2}=0.4675\right.$ and $\mathrm{P}=$ $0.9995)$ in its incidence was observed between the groups.

No significant difference was observed in the IOP between the two groups. Means were highest on the first day post-surgery; however, the recorded values remained within the normal parameters.

On the first day post-surgery, there was discreet central corneal oedema in 50\% of Gfi and $37.5 \%$ of Gfo. However, only one animal presented discreet oedema throughout all the days analysed. No oedema could be seen on Gfo from day 7 up to day 120 post-surgery. No significant difference $\left(\mathrm{X}^{2}=0.0768\right.$ and $\left.\mathrm{P}=0.9995\right)$ in the incidence of central corneal oedema was observed between the groups.

Posterior capsule opacification was observed on all days analysed. No significant difference was observed in the incidence of opacification between the groups, in which it was absent $\left(\mathrm{X}^{2}=\right.$ 2.347 and $\mathrm{P}=0.7994)$, discreet $\left(\mathrm{X}^{2}=1.784\right.$ and $\mathrm{P}=0.8781)$ or moderate $\left(\mathrm{X}^{2}=1.667\right.$ and $\mathrm{P}=$ $0.6444)$ (Table 6). Only two eyes (25\%) showed discreet opacification during the trans-operative period.

Accommodation, glare, consensual and direct pupillary reflexes were normal and no significant difference in their incidence $\left(\mathrm{X}^{2}=0.05615\right.$ and $\mathrm{P}=1.0$ ) was observed between the groups. On day 120 post-surgery, one animal from Gfi showed signs of systemic arterial hypertension, hyphema, flare, conjunctival hyperaemia and absence of accommodation, glare, consensual and direct pupillary reflexes.

\section{DISCUSSION}

In agreement with Azevedo and Ranzani (2006), the intraocular lenses were implanted in the capsular sac with no interference during the postoperative period.

The cataracts were classified according to their stage of maturation and an incidence of $62.5 \%$ mature, $12.5 \%$ hypermature, $12.5 \%$ intumescent, $6.25 \%$ incipient and $6.25 \%$ immature was observed. Klein (2011) studied 179 eyes subjected to PHACO, out of which $35.7 \%$ had presented with immature cataracts, $40.8 \%$ mature and $23.5 \%$ hypermature. In Lin et al. (2011), observed immature cataracts in $58.82 \%$ of dogs, mature in $17.64 \%$ and hypermature in $23.52 \%$. The immature cataract is considered the best stage in which to perform PHACO (Ofri, 2013). 
In this study, blepharospasm and conjunctival hyperaemia were prevalent on day 1 postsurgery. In 2007, Honsho et al. correlated ocular manipulation during surgery with the release of prostaglandins, uveitis, blepharospasm and conjunctival hyperaemia. For this reason, prescribed steroidal and non-steroidal eye drops (Gelatt and Wilkie, 2011).

In 2010, Franzco reported uveitis to be a complication commonly observed during the immediate post-operative period as a consequence of the release of inflammatory mediators. Gordo (2012) suggests that postoperative uveitis is inevitable, due to the manipulation of the intraocular structures during the trans-operative period. The eyes analysed in the present study showed alterations related to uveitis, such as conjunctival hyperaemia, flare, presence of fibrin and synechiae.

The presence of cellular debris from the surgical procedure or uveitis aids the deposit of fibrin in the anterior chamber (Kuner et al., 2004). Thus, heparin was added to the irrigation solution during PHACO in order to reduce the incidence of fibrin, as recommended by Gelatt and Wilkie (2011) and Gordo (2012).

Hypopium and vitreal bands were absent in both groups during the period analysed; however, Taylor et al. (1995) observed hypopium in 25\% of dogs subjected to phakectomy. Gordo (2012) related the presence of vitreal bands in the anterior chamber to the rupture of the lenticular zonules during capsulorhexis, which could damage the ciliary body and lead to hyphema in the immediate post-operative period.

Mydriatics were administered post-operatively in order to prevent synechiae (Gelatt and Wilkie, 2011). Kuner et al. (2004) reported the presence of synechiae in $20 \%$ of operated patients 30 days after surgery. In the present study, synechiae was present in $25 \%$ of the animals of both groups.

The increase in the IOP on the first day after PHACO occurs due to oedema of the trabecular meshwork, presence of residual particles of soluble proteins from the lens and viscoelastic and/or obstruction of the flux of aqueous humour by zonular fragments and inflammatory debris (Honsho et al., 2007; Chiurciu, 2010). In the present study, three animals from Gfi were prescribed hypotensive eye drops for 7 days but only one had to take it for 15 days. In Gfo, one animal was given hypotensive eye drops for 7 days while another animal received it for 30 days. Carbacol was administered, in both groups, to the anterior chamber after the implant of the lens in order to reduce the peaks of IOP during the immediate post-operative period (Gift, 2009).

In dogs, the implant of intraocular lens following PHACO avoids the pressure of the vitreous humour on the posterior capsule of the lens, reducing the incidence of glaucoma (Kleiner, 2012). Glaucoma was not observed in the present study and the IOP remained between 12.80 and $17.30 \mathrm{mmHg}$.

Corneal oedema can be caused by lesions to the corneal endothelium during the trans-operative period by irrigation fluid turbulence, air bubbles and/or fragments of the lens dispersed by the ultrasonic energy from the tip of the PHACO probe (Chiurciu et al., 2010). In some cases, the lesion to the endothelium can be permanent (Gelatt and Wilkie, 2011), as observed in 12.5\% of eyes from Gfi in the present study.

Gift et al. (2009) observed posterior capsule opacification in $93.75 \%$ of operated eyes; however, Gordo (2012) reported opacification in only $55.6 \%$ of dogs. Opacification is caused by the migration of epithelial cells across the capsule of the lens (Gift et al., 2009), which undergoes fibrous metaplasia leading to capsular opacity (Ofri, 2013). Histopathology has revealed that the opacification corresponds to multiple deposits of calcium and magnesium (Travassos et al., 2012).

\section{CONCLUSION}

The implantation of hydrophilic and hydrophobic intraocular lenses in dogs has led to satisfactory results on visual ability, with minimal complications up to 120 days after surgery. No significant difference was observed between the two types of lenses for the parameters studied.

\section{ACKNOWLEDGEMENT}

The authors are thankful to Support and PostGraduate Programs for Private Educational Institutions (PROSUP/CAPES) and PostDoctorate National Program (PNPD/CAPES). 


\section{Guimarães et al.}

\section{REFERENCES}

AZEVEDO, A.B.; RANZANI, J.J.T. Mensuração do segmento anterior do bulbo do olho, visando a estabelecer o tamanho ideal de lentes intra-oculares a serem implantadas em cães. Vet. Not., v.12, p.61-67, 2006

CHIURCIU, J.L.V.; BRANDÃO, C.V.S.; RODRIGUES, A.C.L. et al. Uso de viscoelásticos na facoemulsificação em cães portadores de catarata: efeitos sobre a pressão intraocular, a morfologia das células endoteliais e a espessura corneana. Arq. Bras. Med. Vet. Zootec., v.62, p.570-577, 2010.

DAVIDSON, M.G. Towards a better canine intraocular lens. Vet. Ophthalmol., v.4, p.1, 2001.

FRANZCO, E.C. Complications of cataract surgery. Clin. Exp. Optom., v.93, p.379-389, 2010.

GELATT, K.N.; WILKIE, D.A. Surgical procedures of the lens and cataract. In: GELATT, K.N.; GELATT, J.P. (Eds.). Veterinary ophthalmic surgery. Gainesville: Elsevier, 2011. p.305-352.

GIFT, B.W.; ENGLISH R.V.; NADELSTEIN, B. et al. Comparison of capsular opacification and refractive status after placement of three different intraocular lens implants following phacoemulsification and aspiration of cataracts in dogs. Vet. Ophthalmol., v.12, p.13-21, 2009.

GONÇALVES, G.F.; PIPPI, N.L.; PACHALY, J.R. Pressão intra-ocular em cães com catarata. Arq. Ciênc. Vet. Zool. Unipar, v.8, p.57-61, 2005.

GORDO, I.N.A.S. Complicações da cirurgia de cataratas por facoemulsificação em cães. 2012. 93f. Dissertação (Mestrado em Medicina Veterinária) Universidade Técnica de Lisboa, Portugal.

HONSHO, C.S.; ORIÁ, A.P.; PIGATTO, J.A.T. et al. Extração extracapsular modificada versus facoemulsificação endocapsular: eventos intra e no pós-operatórios imediato. Arq. Bras. Med. Vet. Zootec., v.59, p.105-113, 2007.

KLEIN, H.E.; KROHNE, S.G.; MOORE, G.E. Postoperative complications and visual outcomes of phacoemulsification in 103 dogs (179 eyes): 20062008. Vet. Ophthalmol., v.14, p.114-120, 2011.
KLEINER, J.A. O uso da lentes acrílicas dobráveis ACRIVET $30 \mathrm{~V}$ após cirurgia de catarata em cães. Rev. CFMV, v.18, p.48-52, 2012.

KUNER, A.I.; PEREIRA, J.T.I.; LAUS, J.L. et al. Cirurgia de catarata em cães: observações trans e pósoperatórias em 10 casos. Braz. J. Vet. Res. Anim. Sci., v. 41, p. $57-58,2004$.

LIM, C.C.; BAKKER, S.C.; WALDNER, C.L. et al. Cataracts in 44 dogs (77 eyes): A comparison of outcomes for no treatment, topical medical management, or phacoemulsification with intraocular lens implantation. Can. Vet. J., v.52, p.283-288, 2011.

OFRI, R. Lens. In: MAGGS, D.J.; NILLER, P.E.; OFRI, R. (Eds.). Slatter's fundamentals of veterinary ophthalmology. Gainesville: Elsevier. 2013. p.272290.

PEREIRA, F.D.R.; LIMA, V.L.; REHDER, J.R.C.L. Opacificação do tipo "Snowflake" em lente intraocular de polimetilmetacrilato (PMMA). Rev. Bras. Oftalmol., v.70, p.122-124, 2011.

PIGATTO, J.A.T.; PEREIRA, F.Q.; ALMEIDA, A.C.V.R. et al. Avanços e benefícios da facoemulcificação. Acta Sci. Vet., v.35, p.248-249, 2007.

TAYLOR, M.M.; KERN, T.J.; RIIS, R.C. et al. Intraocular bacterial contamination during cataract surgery. J. Am. Vet. Med. Assoc., v.206, p.1716-1720, 1995.

TEIXEIRA, A.L. Estudo comparativo do estresse oxidativo após facoemulsificação experimental com e sem implante de lentes intra-oculares em cães. 2003. 134f. Dissertação (Mestrado em Medicina Veterinária) - Universidade de São Paulo, S P.

TRAVASSOS, A.; PROENÇA, D.; REGADAS, I. et al. Opacificação de lentes intraoculares a propósito de 44 casos. Oftalmologia, v.36, p.147-154, 2012.

YI, N.Y.; PARK, S.; JEONG, M. et al. Phacoemulsification and acryl foldable intraocular lens implantation in dogs: 32 cases. J. Vet. Sci., v.7, p.281-285, 2006. 